\title{
"The impact of firm size on the performance of Vietnamese private enterprises: A case study"
}

\begin{tabular}{ll} 
AUTHORS & $\begin{array}{l}\text { Cuong Vu Hung } \\
\text { Tuong Phi Vinh (iD } \\
\text { Binh Dang Thai (iD }\end{array}$ \\
\hline ARTICLE INFO & $\begin{array}{l}\text { Cuong Vu Hung, Tuong Phi Vinh and Binh Dang Thai (2021). The impact of firm } \\
\text { size on the performance of Vietnamese private enterprises: A case study. } \\
\text { Problems and Perspectives in Management, 19(2), 243-250. } \\
\text { doi:10.21511/ppm.19(2).2021.20 }\end{array}$ \\
\hline DOI & http://dx.doi.org/10.21511/ppm.19(2).2021.20 \\
\hline RELEASED ON & Wednesday, 09 June 2021 \\
\hline RECEIVED ON & Wednesday, 27 January 2021 \\
\hline ACCEPTED ON & Tuesday, 01 June 2021 \\
\hline LICENSE & $\begin{array}{l}\text { (cc) EY } \\
\text { This work is licensed under a Creative Commons Attribution 4.0 International }\end{array}$ \\
\hline JOURNAL & License \\
\hline ISSN PRINT & Problems and Perspectives in Management" \\
\hline ISSN ONLINE & $1727-7051$ \\
\hline PUBLISHER & $1810-5467$ \\
\hline FOUNDER & LLC “Consulting Publishing Company “Business Perspectives" \\
\hline
\end{tabular}

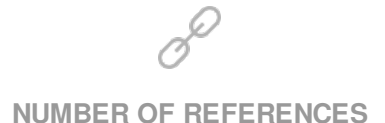

39

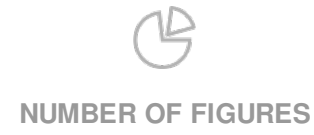

0

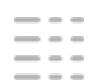

NUMBER OF TABLES

3

(C) The author(s) 2021. This publication is an open access article. 


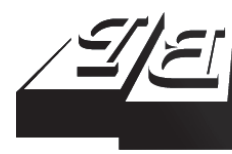

BUSINESS PERSPECTIVES

(O)

LLC "CPC "Business Perspectives" Hryhorii Skovoroda lane, 10 Sumy, 40022, Ukraine www.businessperspectives.org
Received on: $27^{\text {th }}$ of January, 2021 Accepted on: $1^{\text {st }}$ of June, 2021 Published on: $9^{\text {th }}$ of June, 2021

(c) Cuong Vu Hung, Tuong Phi Vinh, Binh Dang Thai, 2021

Cuong Vu Hung, Associate Professor in Economics, Director, Institute of Social Sciences Information, Vietnam Academy of Social Sciences, Vietnam.

Tuong Phi Vinh, Ph.D. in Economics, Deputy Director, Institute of World Economics and Politics, Vietnam Academy of Social Sciences, Vietnam.

Binh Dang Thai, Ph.D. in Economics, Head, Division of Economy and Development Studies, Institute for India and Southwest Asian Studies, Vietnam Academy of Social Sciences, Vietnam. (Corresponding author)

\section{THE IMPACT OF FIRM SIZE ON THE PERFORMANCE OF VIETNAMESE PRIVATE ENTERPRISES: A CASE STUDY}

\begin{abstract}
This article investigates the effect of firm size on the performance of Vietnamese private enterprises. Based on the data from the Annual Enterprise Survey from 2009 to 2018, this study uses an ordinary least-squares regression model (OLS) to point out the effects of firm size (growth rate, total assets, and total labor) on the performance of Vietnamese private enterprises in both static and dynamic states. According to the results of the quantitative model, total assets are the biggest factor for determining firm performance, followed by total labor and growth rate. The results highlight the issue in Vietnamese private enterprises development in terms of scale, despite the fact that their number is growing, as the scale of enterprises decreases (the proportion of micro and small enterprises increases, but the proportion of medium and big enterprises decreases). Besides, the disadvantages of scale also negatively affect the development process of Vietnamese private enterprises, including accessing capital, increase in production or productivity, business expansion, and improving competitiveness.
\end{abstract}

Keywords

OLS model, firm performance, profitability, enterprise development, PCI, private enterprise, Vietnam

JEL Classification D22, L25, O12

\section{INTRODUCTION}

Firm size is among determinant factors of firm performance and particularly shows the profitability of business (Oyelade, 2019; Isik et al., 2017). In the context of international integration, emergence and vast influence of large enterprises-multinational corporations (MNCs) have proved the important role of scale in firm performance and business environment (Babalola, 2013). New economic geography theory and studies show the relationship between the economic growth and the growth of firm size. On the one hand, the economic growth of a country or an area will be based largely on the scale-up of existing institutions (Bhayani, 2010). Otherwise, regarding the economy of scale, enterprises can produce more efficiently, reduce costs, apply technology to production easily, negotiate with suppliers easily, increase competitiveness, and access to capital easily, etc. (Voulgaris \& Lemonakis, 2014; Fiegenbaum \& Karnani, 1991; Lee, 2009).

Over the past decade, in Vietnamese enterprises of the private sector, especially micro and small sized, have been developing based on exploiting the domestic market even though there is dynamic development and significant contribution to the growth of the economy. The small size limits access to capital, the ability to apply innovative technologies, and the capacity to create good quality jobs, which government expects from enterprise development. Besides, the fierce competition with foreign large-scale enterprises with modern technology 
and good managerial ability poses many challenges for Vietnamese private enterprises. Therefore, figuring out the optimal firm size is a current issue for Vietnamese enterprises in general and for private enterprises in particular.

\section{LITERATURE REVIEW}

Firm performance is an interesting topic not only for academic scholars but also for policymakers, in which firm size is one of the main factors deciding the operation of any enterprises (Oyelade, 2019; Khemiri \& Noubbigh, 2019). Majumdar (1997) showed that different sizes could affect the firm performance in various ways. For example, for large enterprises the exploitation of economies of scale, the variety of business activities, the ability to exploit a large market, and the degree of easing administrative procedures essentially influence firm performance. By exploiting economies of scale, large enterprises can increase productivity compared to small enterprises (Liu, 2018). Therefore, based on the economies of scale, large enterprises often work more efficiently than small enterprises.

In addition, the extent of firm size is often associated with the market power of the firm (Shepherd, 1986; Amato \& Wilder, 1985; Voulgaris \& Lemonakis, 2014). Large enterprises have more advantages in negotiating with sellers and suppliers. Big enterprises create market entry barriers for new players (Serrasqueiro \& Nunes, 2008; Ramsay et al., 2005). Hence, they increase market power in the industry (Lee, 2009). Moreover, large enterprises often exploit capital markets as well as public debt markets with lower capital costs (Isik et al., 2017). Large enterprises also have superior resources and capabilities in product development, technology innovation development, and of course better implementation of business strategy, marketing, and e-commerce (Kipesha, 2013). Therefore, large enterprises can operate more efficiently because they have good resources with more efficient use of inputs (Halkos \& Tzeremes, 2007). An outstanding feature of large enterprises is the possession of human capital resources (Pisserides, 2000; Yang \& Chen, 2009). They have a large workforce as well as highly qualified workers and can recruit skilled workers. At the same time, a big impact of large-scale enterprises is the creation of job opportunities for society and communities.
Otherwise, large enterprises have many disadvantages compared to small enterprises. Large enterprises often are mature firms, so they are often not flexible with market and strategy changes (Mankiw, 2018). Meanwhile, with a small-scale small enterprise have more flexibility in managing organization machinery, product innovation, and market approach. In addition, large enterprises will have to spend more on activities to maintain and increase market share such as advertising costs, marketing costs, and expenses to set up distribution channels, etc. (Majumdar, 1997). In particular, some industries (such as e-commerce enterprises) may spend more on advertising and marketing activities. Large enterprises may face inefficiencies due to some constraints such as labor costs, larger related costs, e.g. complex management processes, bureaucratic management, administration, high levels of investment, investment diversion, etc. (Jónsson, 2007; Becker-Blease et al., 2010).

In addition, the relationship between firm size and firm performance is mentioned in various theories: organizational theory, theory of industrial location, theory of strategic management and finance, etc. (Goddard et al., 2005; Doğan, 2013). However, both empirical and theoretical studies provided different results of the relationship between firm size and firm performance as well as optimal firm size for efficiency. Most of the results show a positive relationship between firm size and firm performance. Fiegenbaum and Karnani (1991) studied the relationship between firm size and profitability among 3000 enterprises in the period of 19791987. The results showed a positive relationship between firm size and profitability. Applying the causality test in empirical research for 66 firms in Nigeria in the period of 1999-2007, Anthony Enisan Akinlo (2012) pointed out a long-run steady-state relationship between firm size and firm profitability. The results also indicated that increasing firm size can enhance firm profitability in Nigeria. Similar to the above study, John and Adebayo (2013) used data from 
manufacturing companies on the stock market of Nigeria. This study used total assets and total revenue as variables representing the firm size and return on assets (ROA) as variables being profitability. The results of this study expressed that both total assets and total revenue related to firm size positively influence the profitability of processing and manufacturing enterprises in Nigeria. The study of Isik et al. (2017) also showed the positive effect of firm size on firm performance for processing and manufacturing enterprises in Turkey. Such variables as total assets, total revenue, and total labor were used. These factors represent the firm size and ROA (firm profitability). Analyzing system GMM estimators and research results, a positive relationship between the size and performance for processing and innovative enterprises during the period of 2005-2013 was shown. Besides, Hall and Weiss (1967), Jónsson (2007), Papadogonas (2007), Serrasqueiro and Nunes (2008), Doğan (2013), and Liu et al. (2014) also described positive influence of firm size on firm performance.

On the other hand, the extent of the effect of size on firm profitability is also an inconsistent problem in experimental studies. There are still many studies showing negative effects or no effect of firm size on the profitability of enterprises. Studying financial services sector, Amato and Burson (2007) showed negative impact of firm size on firm profitability. Shehata et al. (2017) also described negative effects of size and profitability. Focusing on 34,798 small and medium-sized UK enterprises in the period of 2005-2013, the study showed negative effect of firm size (proxy by total assets) on firm profitability (proxy by ROA). Many other discoveries illustrated no relationship between firm profitability and firm size (Whittington, 1980; Gonenc et al., 2007; Becker-Blease et al., 2010; Niresh \& Thirunavukkarasu, 2014; Hatem, 2014; Abeyrathna \& Priyadarshana, 2019).

\section{THE AIM OF THE STUDY}

The article focuses on assessing the effects of firm size on the performance of Vietnamese private enterprises. The results of this study will provide more evidence on the relationship between firm size and profitability of private enterprises.

\section{METHODOLOGY}

This research used a combination of data on business results of enterprises and data on business environment assessment. Specifically, secondary data from 2009 to 2018 of 190,499 Vietnamese private enterprises were compiled from the Annual Enterprises Survey by the General Statistics Office of Vietnam and the cleaning data set. Data include information on after-tax profit, business growth rate, total assets, total labor, firm age, and provincial competitiveness index (PCI). After-tax profit is a variable representing firm performance. Growth rate, total assets, and total labor are three variables as the proxy measures of firm size. In addition, firm age and provincial competitiveness index (PCI) are control variables.

Table 1. Descriptive statistics

\begin{tabular}{|c|c|c|c|c|c|}
\hline Variable & Obs & Mean & Std. Dev. & Min & Max \\
\hline Size_Gr & 190,499 & 2086215 & 6969921 & -1 & 4.999388 \\
\hline Size_A & 190,499 & 108920.8 & 868332.5 & 1 & $9.28 e+07$ \\
\hline Size_L & 190,499 & 122.4037 & 765.5562 & 1 & 83722 \\
\hline Age & 190,499 & 11.77561 & 7.28202 & 0 & 84 \\
\hline $\mathrm{PCl}$ & 190,499 & .6033403 & 0396007 & .4511707 & .7595631 \\
\hline Profit & 190,499 & 6617.262 & 85098.63 & .1 & $1.13 e+07$ \\
\hline
\end{tabular}

Based on earlier empirical studies on the relationship between size and firm performance (Babalola, 2013; Sritharan. 2015), to determine the effect of firm size on the performance of Vietnamese private enterprise, the model was proposed as follows:

$$
Y_{i, j, t}=C_{t} \cdot f\left(\text { Size }_{i, j, t}, X_{i, j, t}\right) \text {, }
$$

where $i, j, t$ is the firm, province, and year respectively; $Y$ denote performance of Vietnamese private enterprise, is proxy by profit after tax; $C$ is a constant; Size describe firm size, a proxy by growth rate (Size_Gr), which is measured by the growth of firm revenue, total assets (Size_A), total labor (Size_L); $X$ is the control variables including firm age $(A)$, which is measured by the number of operational years since it was established, and provincial competitiveness index $(P C I)$.

To assess the different influence of firm size on the performance of Vietnamese private enterprise, the model is transferred into the logarithm as follows: 


$$
\begin{aligned}
& \ln \left(\text { Profit }_{i, j, t}\right)=\alpha_{0}+\alpha_{1} \ln \left(\text { Size }_{-} G r\right)+ \\
& +\alpha_{2} \ln \left(\text { Size }_{-} A\right)+\alpha_{3} \ln (\text { Size_L })+ \\
& +\alpha_{4} \ln (\text { Age })+\alpha_{5} P c i+u_{i, j, t} .
\end{aligned}
$$

\section{RESEARCH RESULTS}

The result showed that R-Squared approximate 0.4064 corresponds to $P$-value $=0.000<0.05$, which indicates that all variables: firm size (growth rate, total assets, total labor) and control variables (firm age and provincial competitiveness index) are statistically significant. The variables of the model can accurately explain about $40.64 \%$ of the change in profit of Vietnamese private enterprises.

Table 2. Final estimation result

\begin{tabular}{l|c|c|c|c}
\hline \multirow{2}{*}{$\begin{array}{c}\text { Explanatory } \\
\text { variables }\end{array}$} & Coefficient & Std. Err. & \multicolumn{2}{c}{ Linear log-model } \\
\cline { 3 - 5 } & & & $\mathbf{t}$ & $\boldsymbol{P}$-value \\
\hline In (Size_Gr) & 0.0000202 & $6.42 \mathrm{e}-06$ & 3.15 & 0.002 \\
\hline In (Size_A) & 0.5573719 & 0.0031057 & 179.47 & 0.0000 \\
\hline Ln (Size_L) & 0.3436307 & 0.0036564 & 93.98 & 0.0000 \\
\hline Ln (Age) & 0.2620443 & .007368 & 35.57 & 0.0000 \\
\hline PCl & 3.994296 & .0974554 & 40.99 & 0.0000 \\
\hline Const & -4.490073 & .0609661 & -73.65 & 0.0000 \\
\hline Adj. $R^{2}$ & 0.465 & & & \\
\hline
\end{tabular}

Note: Significant at the $5 \%$ level. $F=26094.16$, Sig. $=0.000$.

Besides, to avoid the problem of multicollinearity, the VIF (Variance inflation factor) test was used for independent variables. The results of the VIF test for the independent variables showed that not all dependent variables have $\mathrm{VIF}<2$. Hence, there is no multicollinearity among the dependent variables, as shown in Table 3.

Table 3. Test for multicollinearity for the selected variables

\begin{tabular}{l|c|c}
\hline \multicolumn{1}{c|}{ Variable } & VIF & 1/VIF \\
\hline Size_Gr & 1 & 0.999754 \\
\hline Size_A & 1.93 & 0.518140 \\
\hline Size_L & 1.86 & 0.537581 \\
\hline Age & 1.08 & 0.925313 \\
\hline PCl & 1.03 & 0.967030 \\
\hline Mean VIF & 1.38 & \\
\hline
\end{tabular}

The results showed that firm size (in both static and dynamic states) positively affects firm performance. The growth of firm size (dynamic state) and total assets (static state) have positive effects on profit of private enterprises with different levels of influence. This finding is very meaningful and consistent with the research on Vietnamese economic reform. This leads to building up a new business due to unemployment, vacation, etc. Profit growth also motivated Vietnamese private enterprises to increase reinvestment and thus, achieve better business results.

The research results showed that among the variables representing the size of private enterprises, total assets is the crucial factor determining firm performance, followed by total labor and growth rate. This is explained by the fact that for Vietnamese enterprises in general (and private enterprises in particular) production and business activities still depend on assets and labor. This is also the general situation of Vietnamese private enterprises, as they are still capital- and labor-intensive.

Besides, the number of employees and total capital of Vietnamese private enterprises grow at different speeds, which leads to a change in business size in terms of both labor and capital criteria. The increase in the number of Vietnamese enterprises faster than the increase in the employee number, which leads to the downsizing of enterprises in terms of labor. The average number of employees in the enterprise has continuously decreased from 49 employees in 2007 to only 29 employees in 2015, corresponding to the size of a small enterprise (Vietnam Chamber of Commerce and Industry, 2018). It reflects the fact that the share of micro and small enterprises in the economy is increasing and Vietnam continues to lack medium enterprises. The downsizing of businesses will force Vietnamese enterprises in general, and the majority of private enterprises in particular, to face a series of difficulties such as economy of scale, difficulty in accessing capital sources, lack of capital and modern technologies, high informal costs, etc. The proportion of informal costs is $64 \%$ for micro-enterprises, $56 \%$ for small enterprises, and $49 \%$ for medium enterprises, while for large enterprises it is only $30 \%$ (Phùng, 2019). Therefore, the operations of the Vietnamese private sector, most of which are micro, small, and medium enterprises, will face more difficulty in competing with foreign enterprises. Vietnam is in the process of deep integration into the world economy where major powers are competing fiercely through their protectionist policies. 
In terms of capital size, the average capital flow of Vietnamese enterprises has increased 1.7 times, from 32 billion VND in 2007 to 53 billion VND in 2015, and 59,77 billion VND per enterprise in 2016, which equals to the size of medium business. The increase in capital size took place in all three types of enterprises, most of which were in the state-owned enterprise sector. The average capital size of state-owned enterprises increased by about 4.25 times, from 616 billion to 2,616 billion (Vietnam Chamber of Commerce and Industry, 2018). This is the result of the process of restructuring and equalization of state-owned enterprises when the state only retains large corporations and proceeds to equitize and mobilize more capital from the private sector. State-owned enterprises continued to have the highest average capital scale, reaching 2,616 billion VND/enterprise in 2015, which is 7 times higher than the average capital scale of FDI enterprises and 95 times higher than the average capital scale of the domestic private enterprises. FDI and domestic private enterprises have similar average growth rates of capital, more than doubling in the period of 2007-2015. Specifically, the average capital size of non-state enterprises increased from 13 billion VND in 2007 to 28 billion VND in 2015, while FDI enterprises increased from 172 billion VND to 373 billion VND (Chamber of Commerce Trade and Industry of Vietnam, 2018). Thus, the increase in the size of capital has helped domestic private enterprises gradually shift from small to medium size in terms of capital, while state-owned enterprises and FDI enterprises have always remained on a big scale. However, although domestic private enterprises have seen an increase in size based on capital criteria, the growth rate has not kept pace with state-owned and FDI enterprises. This has a significant impact on the operational efficiency, investment expansion capacity, capital assessment, technology upgrading, and competitiveness improvement of Vietnamese domestic private enterprises.

Among factors of firm size, growth rate has the smallest positive effect on firm performance. Therefore, it is necessary to review the issue of growth efficiency as well as performance of Vietnamese private enterprises. To evaluate growth efficiency of private enterprises, this study examines the return on assets (ROA) of profitable firms. According to a report by the Chamber of Commerce Trade and Industry of Vietnam (2018), ROA of large and medium-sized Vietnamese enterprises is always the highest and has the same progress, decreasing continuously in the period of 2010-2013 and slightly recovered in 2014-2016. ROA of micro-enterprises, after increasing sharply in 2011-2012 to $7.7 \%$, the highest among enterprises by size, fell sharply to $3.3 \%$ in 2013 and slightly recovered to $3.5 \%$ in 2014 , then decreased to $2.9 \%$ in 2015 before rising sharply in 2016 to $4.5 \%$. ROA of small firms is similar to that of micro firms, but with a narrower margin. In 2011-2014, ROA of small businesses is the lowest. By 2015, ROA of microenterprises continued to decrease by $2.9 \%$, the lowest in the scale of Vietnamese enterprises. In 2018, large enterprises have an ROA of $3.6 \%$; medium enterprises $1.1 \%$; SMEs - $0.3 \%$ and micro firms - $1.1 \%$ (Ministry of Planning and Investment, 2020). This shows that the problem of the quality and efficiency of business growth in Vietnam, in which the majority of enterprises are he private enterprises. It also shows high business uncertainty of micro-and small-sized firms compared to large and medium-sized firms.

In addition to firm size, firm age and provincial competitiveness index also have positive effects on private firm performance. This result is underpinned by the characteristics of Vietnamese private enterprises (namely family-formed). Therefore, the operation of private enterprises is largely based on the experience of owners. Among the factors of the model, PCI is the most influential factor in the performance of private enterprises. The reality shows that institutional and administrative procedures should be simple, compact, and uncorrupted to create favorable conditions for enterprises. Any areas with such a support system can attract more businesses. On the other hand, when enterprises run in areas with favorable conditions and environments, they will operate more effectively. Besides, enterprises will be willing to increase their scale, expand production and business when receiving support from local authorities, as well as institutional and policy transparency, and clearance. 


\section{CONCLUSION}

This study examined the relationship between firm size and firm performance of Vietnamese private enterprises. The results of this research provided evidence that firm size has an important influence on firm performance of Vietnamese private enterprises with different levels. Among the variables of firm size, total assets are the biggest factor determining the firm performance of Vietnamese private enterprises, followed by total labor and growth rate. The results of this study also showed that the development of business size of Vietnamese private enterprises has been ineffective despite the increase in numbers of this sector. To solve this problem, Vietnamese private enterprises need to change from the basic resources-driven growth model to the knowledge-based growth model in the context of the globalization process and increasing competition pressure among Vietnamese enterprises. Besides, local governments need to improve local business environment policies and institutions, create conditions to attract investors, and support more domestic private enterprises to turn the private sector into an important driving force of the economic development.

\section{AUTHOR CONTRIBUTIONS}

Conceptualization: Tuong Phi Vinh, Binh Dang Thai.

Data curation: Tuong Phi Vinh, Binh Dang Thai.

Formal analysis: Cuong Vu Hung, Tuong Phi Vinh.

Funding acquisition: Cuong Vu Hung.

Investigation: Binh Dang Thai.

Methodology: Cuong Vu Hung.

Software: Cuong Vu Hung, Tuong Phi Vinh, Binh Dang Thai.

Supervision: Cuong Vu Hung, Tuong Phi Vinh, Binh Dang Thai.

Writing - original draft: Cuong Vu Hung, Tuong Phi Vinh, Binh Dang Thai.

Writing - review \& editing: Cuong Vu Hung, Tuong Phi Vinh, Binh Dang Thai.

\section{ACKNOWLEDGMENTS}

This research is supported by the National Science Project "Development of Private Enterprises in the Southwest Region in the new context" (KHCN-TNB/14-19/X15).

\section{REFERENCES}

1. Abeyrathna, S. P. G. M., \&

Priyadarshana, A. J. M. (2019).

Impact of Firm size on

Profitability (Special reference to listed manufacturing companies in Sri Lanka). International Journal of Scientific and Research Publications, 9(6), 561-564. http://dx.doi.org/10.29322/IJSRP.9.06.2019.p9081

2. Amato, L. H., \& Burson, T. E. (2007). The effects of firm size on profit rates in the financial services. Journal of Economics and Economic Education Research, 8(1), 67.

3. Amato, L., \& Wilder, R. (1985). The effects of firm size on profit rates in US manufacturing.
Southern Economic Journal, 52(1), 181-190. https://doi. org/10.2307/1058913

4. Anthony Enisan Akinlo. (2012). Firm size-profitability nexus: evidence from panel data for Nigeria. Economic Research Ekonomska Istrazivanja, 25(3), 706-721. https://doi.org/10.1080/1 331677x.2012.11517530

5. Babalola, Y. A. (2013). The Effect of Firm Size on Firms Profitability in Nigeria. Journal of Economics and Sustainable Development, 4(5), 90-94. Retrieved from https:// www.iiste.org/Journals/index.php/ JEDS/article/view/4857
6. Becker-Blease, J. R., Kaen, F. R., Etebari, A., \& Baumann, H. (2010). Employees, firm size and profitability in US manufacturing industries. Investment Management and Financial Innovations, 7(2), 7-23. Retrieved from https://www.businessperspectives.org/images/pdf/applications/publishing/templates/article/ assets/3235/imfi_en_2010_02 Becker.pdf

7. Bhayani, S. J. (2010). Determinant of Profitability in Indian Cement Industry: An Economic Analysis. South Asian Journal of Management, 17(4), 6-20. Retrieved from https://www. 
semanticscholar.org/paper/Determinant-of-Profitability-in-IndianCement-An-Bhayani/6bf6d3ee14d 692023437fad5f578e3d089cde4ae

8. Dogan, M. (2013). Does Firm Size Affect the Firm Profitability? Evidence from Turkey. Research Journal of Finance and Accounting, 4(4), 53-59. Retrieved from https:// www.iiste.org/Journals/index.php/ RJFA/article/view/4977

9. Fiegenbaum, A., \& Karnani, A. (1991). Output Flexibility - A Competitive Advantage for Small Firms. Strategic Management Journal, 12, 101-114. https://doi. org/10.1002/smj.4250120203

10. Goddard, J., Tavakoli, M., \& Wilson, J. O. S. (2005). Determinants of profitability in European manufacturing and services: Evidence from dynamic panel model. Applied Financial Economics, 15(18), 1269-1282. https://doi. org/10.1080/09603100500387139

11. Gonenc, H., Kan, O. B., \& Karadagli, E. C. (2007). Business groups and internal capital markets. Emerging Markets Finance and Trade, 43(2), 63-81. https://doi.org/10.2753/REE1540496X430204

12. Halkos, G. E., \& Tzeremes, N. G. (2007). Productivity efficiency and firm size: An empirical analysis of foreign owned companies. International Business Review, 16(6), 713-731. https://doi. org/10.1016/j.ibusrev.2007.06.002

13. Hall, M., \& Weiss, L. (1967). Firm Size and Profitability. The Review of Economics and Statistics, 49(3), 319-331. https://doi. org/10.2307/1926642

14. Hatem, B. S. (2014). Determinants of firm performance: A comparison of European countries. International Journal of Economics and Finance, 6(10), 243-249. https://doi.org/10.5539/ ijef.v6n10p243

15. Isik, O., Unal, E. A., \& Unal, Y. (2017). The effect of firm size on profitability: evidence from Turkish manufacturing sector. Journal of Business, Economics and Finance (JBEF), 6(4), 301-308.
http://dx.doi.org/10.17261/Pressacademia.2017.762

16. John, A. O., \& Adebayo, O. (2013). Effect of firm size on profitability: Evidence from Nigerian manufacturing sector. Prime Journal of Business Administration and Management (BAM), 3(9), 1171-1175.

17. Jónsson, B. (2007). Does the size matter? The relationship between size and profitability of Icelandic firms. Bifröst Journal of Social Sciences, 1, 43-55. Retrieved from https://citeseerx.ist.psu.edu/viewdoc/download?doi=10.1.1.508.420 $2 \&$ rep $=$ rep $1 \&$ type $=$ pdf

18. Khemiri, W., \& Noubbigh, H. (2020). Size-threshold effect in debt-firm' performance nexus in the sub-Saharianregion: A Panel Smooth Transition Regression Approach. Quarterly Review of Economics and Finance, 76, 335344. https://doi.org/10.1016/j. qref.2019.09.009

19. Kipesha, E. F. (2013). Impact of Size and Age on Firm Performance: Evidences from Microfinance Institutions in Tanzania. Research Journal of Finance and Accounting, 4(5), 105-116. Retrieved from https:// www.iiste.org/Journals/index.php/ RJFA/article/view/5091

20. Lee, J. (2009). Does Size Matter in Firm Performance? Evidence from US Public Firms. International Journal of the Economics of Business, 16(2), 189-203. http://doi. org/10.1080/13571510902917400

21. Liu, Y. (2018). Firm Age, Size, and Employment Dynamics: Evidence from Japanese firms (RIETI Discussion Paper Series 18-E-006). The Research Institute of Economy, Trade and Industry. Retrieved from https://ideas.repec.org/p/eti/ dpaper/18006.html

22. Liu, Y., Wei, Z., \& Xie, F. (2014). Do women directors improve firm performance in China? Journal of Corporate Finance, 28, 169-184. https://doi.org/10.1016/j.jcorpfin.2013.11.016

23. Majumdar, S. K. (1997). The Impact of Size and Age on Firm-Level Performance: Some
Evidence from India. Review of Industrial Organization, 12, 231-241. Retrieved from https:// link.springer.com/article/10.1023 /A:1007766324749

24. Mankiw, N.G. (2018). Principles of Economics ( $8^{\text {th }}$ ed.). Boston, MA: Cengage Learning. Retrieved from https://www.cengagebrain.co.uk/ shop/isbn/9781305585126

25. Ministry of Planning and Investment. (2020). 2020 Vietnamese enterprise white book (Statistical Report). Retrieved from https://www.gso.gov.vn/dulieu-va-so-lieu-thong-ke/2020/04/ sach-trang-doanh-nghiep-vietnam-nam-2020/

26. Niresh, A., \& Thirunavukkarasu, V. (2014). Firm size and profitability: A study of listed manufacturing firms in Sri Lanka. International Journal of Business and Management, 9(4). https://doi. org/10.5539/ijbm.v9n4p57

27. Oyelade, A. O. (2019). The impact of firm size on firm's performance in Nigeria: a comparative study of selected firms in the building industry in Nigeria. Asian Development Policy Review, 7(1), 1-11. Retrieved from https://ideas. repec.org/a/asi/adprev/2019p1-11. html

28. Papadogonas, T. A. (2007). The financial performance of large and small firms: Evidence from Greece. International Journal of Financial Services Management, 2(1/2), 1420. Retrieved from https://econpapers.repec.org/article/idsijfsmg/v_ 3a2_3ay_3a2007_3ai_3a1_2f2_3ap -3a14-20.htm

29. Phùng, T. Đ. (2019). Hỗ trợ doanh nghiệp nhỏ và vưa Việt Nam phát triên trong giai đoạn hiện nay. Tạp chí Tài chính kỳ 1 tháng, 10/2019. Retrieved from http://tapchitaichinh.vn/tai-chinh-kinh-doanh/ ho-tro-doanh-nghiep-nho-vavua-viet-nam-phat-trien-tronggiai-doan-hien-nay-314736.html

30. Pissarides, A. C. (2000). Equilibrium unemployment theory ( $2^{\text {nd }}$ ed.). Cambridge: The MIT Press. Retrieved from https://ideas.repec.org/b/mtp/ titles/0262161877.html 
31. Ramsay, B., Ong, D., \& Yeung, M. (2005). Firm Size, Ownership and Performance in the Malaysian Palm Oil Industry. Asian Academic of Management Journal of Accounting and Finance, 1, 81104. Retrieved from https://ideas. repec.org/a/usm/journl/aamjaf00101_81-104.html

32. Serrasqueiro, Z. S., \& Nunes, P. M. (2008). Performance and size: empirical evidence from Portuguese SMEs. Small Business Economics, 31(2), 195-217. http:// dx.doi.org/10.1007/s11187-0079092-8

33. Shehata, N., Salhin, A., \& ElHelaly, M. (2017). Board diversity and firm performance: evidence from the UK SMEs. Applied
Economics, 49(48), 4817-4832. https://doi.org/10.1080/00036846. 2017.1293796

34. Shepherd, W. G. (1986). On the Core Concepts of Industrial Economics. In H. W. De Jong \& W. G. Shepherd (Eds.), Mainstreams in Industrial Organization. Dordrecht: Martinus Nijhoff Publishers.

35. Sritharan, V. (2015). Does firm size influence on firm $\mathbb{\Delta} \mathrm{s}$ Profitability? Evidence from listed firms of Sri Lankan Hotels and Travels sector. Research Journal of Finance and Accounting, 6(6), 201-207.

36. Vietnam Chamber of Commerce and Industry. (2018). Vietnam enterprise annual report 2017/2018.
Information and communications publishing house, 2018

37. Voulgaris, F., \& Lemonakis, C. (2014). Competitiveness and profitability: The case of chemicals, pharmaceuticals and plastics. The Journal of Economic Asymmetries, 11, 46-57. https://doi.org/10.1016/j. jeca.2014.04.003

38. Whittington, G. (1980). The Profitability and Size of United Kingdom Companies. The Journal of Industrial Economics, 28(4), 335-352. https://doi. org/10.2307/2098066

39. Yang, C., \& Chen, K. (2009). Are small firms less efficient? Small Business Economics, 32(4), 375395. https://doi.org/10.1007/ s11187-007-9082-x 